\title{
Lung Obstructive Function Score 2
}

National Cancer Institute

\section{Source}

National Cancer Institute. Lung Obstructive Function Score 2. NCI Thesaurus. Code C131057.

FEV1 40-59\%. 